\title{
RACISM ISSUE IN JERICHO BROWN'S SELECTED POEMS
}

\author{
Ramli $^{\mathbf{1}}$ Rikki $^{\mathbf{2}}$ \\ ${ }^{1}$ Universitas Borneo Tarakan \\ ${ }^{2}$ Universitas Bosowa \\ ramli26@borneo.ac.id
}

\begin{abstract}
The aim of this research was to find out the racial issues in the selected poems and its impact towards the black people. This research used descriptive method with social approach. The data was conducted by reading the poems, taking notes of important parts then compiling the related data. The results showed that in Jericho Brown's selected poems many issues of racism were found both from the past and the present life. Racism types like discrimination, injustice, skin color, segregation and slavery were mostly dominated. Besides, racist acts were also experienced by black people in the form of oppression, death, hunger, and death which brought a bad impact to their life. It can be concluded that hose selected poems (the tradition, at the end of hell, and Langston blue) presented a description how white skin treated black people in their lifetime.
\end{abstract}

Keywords: racism, social approach, poetry

\section{INTRODUCTION}

The sense of literature can be divided into written literature or oral literature. Damono (1979: 1) stated that a social form using the language of media, namely literature comes from the creation of the social environment. Social reality is life itself that is created from literary writing. Therefore, literature can be interpreted as a source or reference that contains information that has advantages or benefits in the field of Education or in other fields. According to Marcus and Sollor (2009: 12) literature means not only what is written but also what is voiced with expressions. Besides that, literature is a writing which is distinguished from its beauty connected with positive things (Nandi 1996: 127).

Talking about literature, there were several literary works including poem. Poem is the expression of ideas and feelings through imaginative rhythms and words creating beauty to express their sonorous effects (Tomlinson, 1999: 38). According to Ade and Okunove (2008: 3), poem as a literary work expresses a person's feelings,

\section{British, Jurnal Bahasa dan Sastra Inggris}


thoughts and also specific aspects of their experience. Therefore, the interpretation of poet's feelings was translated into beautiful, deep, and emotional writing.

Literary work is an actual expression of artistic imagination as a manifestation in the lives of people who were densely packed, using short language resulted a good positive impact on the wider community (Esten,1978: 9).Writing or creating a work does not need to use long sentences, even just a few words are able to convey a long meaning. Hudson (1958: 94) stated that literature describes a very broad scope of life despite its own desires to make an object in literary work. In other words, literature is a reflection of an expression of one's own intuitive life. Hence, literary works are created through self-reflection in the form of sentences. Many types of literary works consist of poetry, rhymes, romances, novels, short stories, fairy tales, legends, drama and poems. It looks very simple but still promising a deep meaning making the reader thinks and imagines to reach the pleasure (Anindita, 2017: 19).

Poetry is one of the ways to convey the aspirations of beauty, peace, cruelty and even criminal acts happened in a certain area. Every time the taste and concept of aesthetic change (Pradopo, 2000: 3). Many writers wrote their own experiences through the contents of the poem to sound the social issues like racism. Lustig (2003: 24) said that for those who have a big power used to oppress and exploit other people. The term called racism evokes enthusiasm and emotional reaction.

Racism expresses a different reaction in mankind decision. Human differentiation based on categories or characteristics of skin color and face shape is racist (Liliweri, 2005: 21). Racism is a relationship between the casual and physical characteristics inherited from parents and culture embrace or a combination of the two different races (Daldjoeni, 1991: 81). Racism is expressed as an action based on a lowered belief on history itself by distinguishing groups or individuals based on religious and racial characteristics.

Skin color is prejudice among black individuals, in view of skin shading, exemplified in wording. Bias is pre-appraisal as an evaluation of items and

\section{British, Jurnal Bahasa dan Sastra Inggris}


individuals that are not founded in information or experience. Cox (1973: 2) stated that racism is an event, a situation that evaluates various actions and values in a group based on its cultural perspective which views all social values of other communities outside them as a mistake and even unacceptable. Individuals of color have an extraordinary history in the US that start in the social and financial abuse of African subjugated people groups and their relatives. The uniqueness of the Dark involvement with the U.S. Much can be found out about strength, inventiveness, penance, mistreatment and freedom through the viewpoint of black people groups' encounters in the U.S (Opie 2017: 12).

Prejudice produces horrible and determined mental, social and intergenerational wounds. An apparent hole exists in administrations, proficient schooling and abilities to address the psycho-social impacts of this perplexing issue. The complicity of quiet in both prevailing and subjected bunches increases to its propagation. A shortage of screening and evaluation instruments is an obstruction in distinguishing people whose psychological well-being and dependence issues may have hidden prejudice. Formation of network mending circles is suggested as a favored technique over individual "treatment" to uncover and deconstruct prejudice, reinforce ethnic personality and intergenerational recuperating (Lee 2018:1-14). In the UK, regardless of declining paces of congestion and disappointment among black and minority ethnic families throughout the most recent 10 years, these family units keep on encountering more elevated levels of disappointment, congestion and destitution than white families. Racial separation, bigoted antagonism and brutality, and expanding divisions of payment and abundance join to create a ground-breaking set of outer imperatives on the lodging decisions of dark and minority ethnic families (Law 2008:13-21).

Racism is still very urgent to analyze because in the colonial era of racism, even today racism still exists among the people. Racism does not only occur in middle class people, even those who have high positions still experience racism. Another

\section{British, Jurnal Bahasa dan Sastra Inggris}


reason is wanting to find out why someone can commit racism even when a country is independent and another reason is because racism is a trended issue in the world. Literature is able to mediate the delivery of messages. Everyone is expected to read the message of poems and avoid to race other people.

This study, the researchers did not examine all Jericho Brown's poems but only focused on analyzing three selected poems entitled The Tradition, At the End of Hell, and Langstone Blue. Those three poems contained the same issue of racism towards black people.

Previous research (Wulandari, 2018; Martin, 2008; Hardianti, 2016) discussed about the types of racism in poems in the aspect of homology and found how racism was reflected in the poems. Meanwhile, in this present research the focuswas interested to analyze the racism issues portrayed and the impact of racism. This research was expected to broaden the readers' insight about racism.

\section{RESEARCH METHOD}

Research design consisted of the plan and the procedure for research which focused on the data source, procedure of data collection and data analysis. The type of this research was mostly descriptive qualitative research. Bogdan and Biklen in a book (1982) entitled Qualitative Research for Education: An Introduction to Theory and Method, qualitative research might be utilized as the essential system for information assortment, or perception, report investigation or might be different procedures. The derivative of qualitative research used was document study which aimed to find the meaning of the poem. The reason of the researchers used the theory because in this theory, the researchers could interpret written material based on the context and explore the contents of the thoughts of the authors contained in the manuscript.

In this study, the researchers chose poem as the source of the data. The three of poems entitled The Tradition, At End of Hell and Langstone Blue by Jericho Brown. The data was analyzed in several steps. First step, the researchers comprehended

\section{British, Jurnal Bahasa dan Sastra Inggris}


Jericho Brown poems related to the racial issues. Second step, the researchers described the impact of racial discriminations in aspect of meaning. In this section, the researchers divided each point and explained it according to the types of racist and meaning. Third step, the researchers analyzed the impact of racial discriminations that was portrayed in some of selected Jericho Brown's poems. In this section, the researchers analyzed what types of racism were found.

\section{RESEARCH FINDING AND DISCUSSION}

The following was the findings towards racism obtained in the three poems of Jericho Brown. In this data, the researchers analyzed the meaning and purpose of the issue. Based on the analysis, the researchers also examined the impact that occurred as a result of these racist acts. Meanwhile, in analyzing the data, various data were found including symbols which have their own meaning.

\section{Racism Issue Portrayed}

"The Tradition" by Jericho Brown described injuries in the past and present life. Black people especially males were in pain. Some data were identified as racism issue. While, in "Langstone Blue" which was inspired by the poetic Langstone Huge and published in 2010. In this poem, Brown talked about the suffering of black people happened in the past. There were fourteen issues categorized as racism. In "At the End of Hell", there were three racism issues. Jericho described a person who is in love with a black person whose teeth slits. This poem elaborated the racist actions experienced by hot-skinned people.

\section{Impact of Racism}

In the previous explanation, the poem entitled "The Tradition" explored about the past and present injuries experienced by black people. In Langstone Blue poem there were many bad effects experienced by black people. This poem also described the actions of white people against black people in the past also in At the End of Hell this poem discussed the actions taken by black people who were not generally known. Therefore, the various impacts that can be taken from the three poems as follows:

\section{British, Jurnal Bahasa dan Sastra Inggris}


In the poem entitled "The Tradition" the researchers could find the aftermath of the racist act itself. In the poem Jericho explained that because of the prejudices of black people, they feel that they are useless. There were 3 issues occurred as racism impact in this poem; uselessness, inappropriate education and death.

In the poem entitled "Langstone Blue" the researchersfound4 data of racism impact; lost their territory or home, painfulness, despair and mental illness. Moreover, in the poem entitled "At the End of Hell" the researchers found 11 data of racism impact which are rioting, robbing, selling themselves, increasing suspicion and vigilance, increasing sensitivity to various threats, their defensive attitude would increase and avoid anything new, increasing sensitivity to circumstances that allow them to feel disrespected, humiliated, and avoiding all risks.

This section presented discussion based on the findings of the research on the issue of racism portrayed in Jericho Brown's selected poems and the impact of racism applying the theory of Bogdan and Biklen (1982: 2). The researchers specifically examined how racial issues can be found.From these data it showed that by using the qualitative method, some racist issues found in Jericho Brown's three poems entitled the tradition, at the end of hell, and Langstone blue and contained the impacts as a result of racist actions.

This research supported and enriched the existing theories by expanding the thinking about racist issues and racist actions itself and enriching the previous theory by providing knowledge to convey racist impacts on black people which was not covered the by previous researchers.

The previous study showed that intolerance or racism happened in five perspectives. First, attacking that regularly end up blacking individuals in Britain. Second, adding to deliberate shamefulness and social imbalance. Third, Interest convergence or material determinism interest combination is a racial practice to push the whites monetarily or physically influences their inclination as prevalent class toward blacks. Fourth, Voice of Color. Fifth, Social Construction with race and

\section{British, Jurnal Bahasa dan Sastra Inggris}


prejudice are results of social idea and connection (Wulandari, 2018). In the explanation above, the researchers supported these results. The previous studies enriched the results of this study by adding several types of acts of racism, including discrimination, prejudice, segregation, exploitation, slavery, and skin color that happened to black people.

Moreover, the results of this research also showed that racist actions brought a big impact, one of which was very common, namely continued trauma. The relationship among races that were controlled was very unbalanced where those who understood the racism got an advantage while others got immeasurable loss of the price they experienced. Basically, racism had a very bad effect on social relations in society. The impact that would occur for the race that was discriminated against they would be restrained, got a lot of oppression controlled by the races, even if they fought would only experience failure and more terrible suffering (Irab, 2007: 55-56).

The racist impact on black people in the three poems conveyed the racist influence directly and indirectly. This research had many shortcomings because it did not generally explain the various ways of collecting data and other ways of processing it. This study could be developed by examining the whole of Jericho Brown's poems by taking data about racist issues not only taking from visible sentences but also in general poem which mostly uses symbols to convey messages.

\section{CONCLUSION AND SUGGESTION}

Various types of racist acts were found in three of Jericho Brown's poems. In The tradition, the researchers found racism types of in justice, colonialism, slavery and segregation. Injustice and discrimination dominated. Meanwhile, in the end of hell, the researchersfound racism types of injustice, discrimination, slavery, skin color, prejudice, segregation and exploitation. The act of discrimination and prejudice dominated, while in langstone blue, racist acts were in the form of segregation, skin color, discrimination and prejudice. The racist type of skin color is very dominant. The racist actions brought many negative impacts for the black people. Racist actions

\section{British, Jurnal Bahasa dan Sastra Inggris}


caused prolonged trauma, homelessness, pain, mental illness, and the worst is intentional death for the sufferer or the black people. Meanwhile, there are various ways to address racist acts committed by white people and indirectly found that various types of racist acts potentially result death or just pain.

This study can broaden the readers' insight and guide the students. The readers can apply various messages from Jericho Brown's poem like "black people are human as well as white people". It is also suggested for readers to understand racism widely. This study can be used as more reliable sources for better analysis of racism. This research is far from perfect so that the author will accept and listen to all kinds of good and bad criticism about this research to make it more proper in the future.

\section{REFERENCES}

Ade, O., \& Okunoye. (2008). Introduction to Literature and Literary Criticism. Nigeria: National Open University of Niggeria.

Anindita, K. A. (2017). Pengenalan ilmu sastra. Under graduate Thesis. Bandung: Angkasa.

Bogdan, R. C., \& Biklen, S. K. (1982). Qualitative Research for Education: An Introduction to Theory and Method. New York: Prentice-Hall, Inc.

Brown, J. (2019). The Tradition. America: Copper Canyon Press.

Cox, O. C. (1973). Encyclopedia of Race and Ethnic Study. America: university of Pennsylvania

Daldjoeni, N. (1991). Ras-Ras Umat Manusia Biografis, Kultur historis, Sosiopolitis. Bandung: Citra Aditya Bakti

Damono, S. D. (1979). Sosiologi Sebuah Pengantar. Jakarta: Pusat Pembinaan dan Pengembangan Bahasa Departemen Pendidikan dan Kebudayaan

Eagleton, T. (1988). Teori Kesusasteraan Satu Pengenalan. Kuala Lumpur: Dewan Bahasa dan Pustaka Kementerian Pendidikan Malaysia.

\section{British, Jurnal Bahasa dan Sastra Inggris}


Hardianti, R. R. (2016). Racism Reflected in Maya Angelou's Poem.UndergraduateThesis.Kolaka: Univesitas Sembilan belas November Kolaka

Hudson, W. H. (1958). An introduction to the Study of Literature. London: Royal Holloway University of London

Law, I. (2008). Tackling what lies beneath the surface: The racism reduction agenda and global, EU and UK approaches to tackling racist hostility. Housing, Care and Support, 11(2), 13-21. doi:10.1108/14608790200800012

Lee, B. et al. (2018). Breaking the silence of racism injuries: a community-driven study. International Journal of Migration, Health and Social Care, Vol. 14 No. 1, 1-14. doi:10.1108/IJMHSC-01-2016-0003

Liliweri, A. (2005).Prasangkadankonflik,Komunikasi Lintas BudayaMultikultur. Yogyakarta: LKiS

Marcus, G. \&Sollors W. (2009). A new Literary History of America. America: The Belknap Press dari Harvard University Press

Marguerite L. S. (1985). Enviromental Racism and Black Theology. Amerika: Black Well. Publishers Inc USA.

Martins, F. (2008). Racism in Brazilian Aquarelle - The Place of Denying. International Journal of Migration, Health and Social Care, 4(2), 37-46.

Nandi, D. R. (1996). InovasiPembelajaransastra.Cendekia: Journal of Education and teaching, 10(1), 101-108.

Opie, T., \& Roberts, L. M. (2017). Do black lives really matter in the workplace? Restorative justice as a means to reclaim humanity. Equality, Diversity and Inclusion: An International Journal, 36(8),707-71. doi:10.1108/edi-07-20170149

Tomlinson. (1999). Essential of Children Literature Fourth Edition. USA: Allyn and Bacon.

Wulandari, R. (2018). Racism in Benjamin Zephaniah Selected Poems.UndergraduateThesis.Malang: Universitas Islam NegeriMaluana Malik Ibrahim Malang

\section{British, Jurnal Bahasa dan Sastra Inggris}

